\title{
PENGARUH BRAND IMAGE DAN BIAYA PENDIDIKAN TERHADAP \\ KEPUTUSAN MAHASISWA DALAM MEMILIH PROGRAM STUDI MANAJEMEN DI STIE RAHMANIYAH SEKAYU (STUDI KASUS MAHASISWA PROGRAM STUDI MANAJEMEN ANGKATAN 2013/2014)
}

\author{
Ade Nia Suryani \\ Sekolah Tinggi Ilmu Ekonomi Rahmaniyah \\ Email: adenia_suryani@yahoo.com
}

\begin{abstract}
ABSTRAK
This study aims to determine: (1) the influence of brand image and cost of education partially to the student's decision in choosing Management Study Program at STIE Rahmaniyah Sekayu, (2) influence of brand image and educational cost simultaneously to student decision in choosing Management Studies Program STIE Rahmaniyah Sekayu. This research is a causality research. The population of this study is a student of Management Studies Program of 2013/2014 as much as 360 people. The number of samples of 79 people was determined using Slovin formula with a margin of error of $10 \%$. The sample was chosen by using purposive sampling technique. Data were collected by using questionnaire method and analyzed by using multiple linear regression analysis. The result of the research shows that (1) brand image have an effect on student's decision in choosing Management Study Program at STIE Rahmaniyah Sekayu, (2) education cost influence to student decision in choosing Management Study Program at STIE Rahmaniyah Sekayu, (3) brand image and cost of education influence student's decision in choosing Management Study Program at STIE Rahmaniyah Sekayu.
\end{abstract}

Keywords: brand image, cost of education, student's decision.

\section{PENDAHULUAN}

Sebagai lembaga pendidikan tinggi, perguruan tinggi memiliki peran yang sangat penting dalam mendidik, mengelola dan menghasilkan sumber daya manusia yang berkualitas. Dengan demikian diharapkan para lulusannya dapat berguna dan diterima oleh masyarakat, serta dapat diserap dengan baik oleh lapangan kerja. Akan tetapi untuk mewujudkan hal tersebut diperlukan suatu usaha dan strategi yang tepat mengingat semua perguruan tinggi memiliki tujuan yang sama.

Seperti halnya perusahaan manufaktur yang menghasilkan produk barang, perguruan tinggi sebagai penghasil produk jasa juga harus melakukan berbagai upaya di dalam menghadapi persaingan yang semakin ketat dalam industri pendidikan. Setiap perguruan tinggi harus jeli dalam melihat peluang yang ada di masyarakat. Kecenderungan masyarakat adalah memilih perguruan tinggi yang tidak hanya terakreditasi baik, tetapi juga memiliki citra merek (brand image) yang baik di mata masyarakat.

Citra merek (brand image) yang baik dalam jangka panjang dapat membawa dampak yang positif bagi perguruan tinggi, karena dengan sendirinya dapat menjadi daya tarik bagi masyarakat. Oleh karena itu, penting sekali bagi perguruan tinggi untuk mempertahankan dan meningkatkan citra merek (brand image) yang sudah terbentuk dengan selalu melakukan evaluasi terhadap kinerja perguruan tinggi yang bersangkutan. 
Selain citra merek ada juga faktor lain yang dapat mempengaruhi keputusan dalam memilih perguruan tinggi yaitu biaya pendidikan. Ada kecenderungan untuk membandingkan antara biaya pendidikan dengan kualitas layanan yang diterima. Sehingga penting untuk diperhatikan oleh perguruan tinggi jika menginginkan kepercayaan masyarakat tetap terjaga.

Sekolah Tinggi Ilmu Ekonomi Rahmaniyah Sekayu (STIER) merupakan salah satu perguruan tinggi swasta yang ada di Sumatera Selatan tepatnya di Kabupaten Musi Banyuasin. STIER berdiri pada tanggal 10 Mei 1999 dengan membuka Program Studi S1 Manajemen dan Program Studi D3 Akuntansi. Kemudian Program Studi S1 Akuntansi berdiri pada tahun ajaran 2006/2007. Hingga saat ini STIER memiliki jumlah mahasiswa sebanyak 2096 orang yang terdiri dari 1572 orang mahasiswa Program Studi S1 Manajemen dan 524 orang mahasiswa Program Studi S1 Akuntansi. Besarnya animo para lulusan sekolah menengah atas (SMA) di Musi Banyuasin dalam memilih STIER terutama Program Studi Manajemen sebagai tempat untuk melanjutkan pendidikan tentunya ada dipengaruhi oleh faktor-faktor positif yang dilihat oleh para lulusan SMA tersebut.

Berdasarkan latar belakang yang telah dikemukakan di atas maka rumusan masalah dalam penelitian ini adalah: (1) Adakah pengaruh brand image dan biaya pendidikan secara parsial terhadap keputusan mahasiswa dalam memilih Program Studi Manajemen di STIE Rahmaniyah Sekayu, (2) Adakah pengaruh brand image dan biaya pendidikan secara simultan terhadap keputusan mahasiswa dalam memilih Program Studi Manajemen di STIE Rahmaniyah Sekayu.

\section{KAJIAN PUSTAKA}

\section{Brand Image}

Brand (Merek) adalah salah satu atribut yang sangat penting dari sebuah produk yang penggunaanya pada saat ini sudah sangat meluas karena beberapa alasan, dimana merek suatu produk berarti memberikan nilai tambah produk tersebut. Pikiran para pelanggan dipengaruhi oleh beragam pesan yang sampai pada angka ribuan pesan dan sering berubah - ubah. Merek tidak hanya kesan - kesannya, tetapi merek juga harus menempati suatu posisi khusus dalam pikiran untuk benar - benar menjadi sebuah merek. Permasalahanya bila merek tidak mendapat tempat khusus atau berbeda dalam benak konsumen, maka akan memberi kesempatan bagi para pesaing untuk menempati posisi dalam benak konsumen tersebut dan merek itu menjadi kurang sejati. Oleh karena itulah maka diperlukan apa yang dinamakan dengan merek sejati. Merek sejati terdiri dari tiga hal yang merupakan sifat fundamental yang membedakan merek sejati dalam benak konsumen yakni internalisasi jumlah kesan - kesan, suatu khusus di "pikiran (mind's eye)" konsumen, dan manfaat - manfaat fungsional dan emosional yang dirasakan. Secara definitif merek sejati dapat dijelaskan sebagai internalisasi jumlah dari semua kesan yang diterima para pelanggan dan konsumen yang dihasilkan dalam sebuah posisi khusus di "pikiran" konsumen berdasarkan manfaat - manfaat fungsional dan emosional. Cara yang paling mudah untuk membedakan merek sejati dengan merek lain adalah dengan melihatnya pada serangkaian kesatuan yang membandingkan kekhususan relatif. Jika merek menjadi khusus dalam benak konsumen, maka merek tersebut lebih mendekati definisi merek sejati. Definisi lain tentang merek dijelaskan oleh Kotler dan Gary Armstrong (2012) dalam bukunya Prinsip-Prinsip Pemasaran. Menurut mereka merek adalah nama, istilah, tanda, simbol, rancangan, atau kombinasi dari semua ini yang dimaksudkan untuk mengenali produk atau jasa dari seseorang atau penjual dan untuk membedakannya dari produk pesaing. Jadi merek mengidentifikasi pembuat atau penjual dari suatu produk. Merek juga merupakan janji penjual untuk menyampaikan kesimpulan sifat, manfaat, dan jasa spesifik secara konsisten kepada pembeli. Merek dapat menyampaikan empat tingkat arti: 
1. Atribut. Merek akan mengingatkan orang pada atribut tertentu. Misalnya keawetan dan sebagainya sehingga hal ini memberikan suatu landasan pemosisian bagi atribut lain dari produk tersebut

2. Manfaat. Pelanggan tidak membeli atribut tetapi mereka membeli manfaat dari produk tersebut. Oleh karena itu atribut harus diterjemahkan menjadi manfaat fungsional dan emosional.

3. Nilai. Merek juga mencerminkan sesuatu mengenai nilai - nilai pembeli. Misalnya saja menilai prestasi, keamanan, dan prestise tinggi suatu produk.

4. Kepribadian. Merek menggambarkan kepribadian. Merek akan menarik orang yang gambaran sebenarnya dan citra dirinya cocok dengan citra merek.

Image berkaitan dengan sesuatu yang melekat pada suatu produk atau jasa dimata konsumen. Menurut Assael (1992), image merupakan keseluruhan persepsi terhadap objek yang dibentuk oleh konsumen melalui pemrosesan informasi dari berbagai sumber setiap waktu yang terbentuk melalui penggambaran dan asosiasi secara keseluruhan tentang merek dan produk dari stimuli lingkungan dan menggambarkan asosiasi terhadap produk dan jasa secara internal dengan mengembangkan unsur fantasi. Sedangkan menurut Kotler dan Keller (2007) merek adalah produk atau jasa penambah dimensi yang dengan cara tertentu mendiferensiasikannya dari produk atau jasa lain yang dirancang untuk memuaskan kebutuhan yang sama.

Dari pengertian tersebut, maka dapat disimpulkan bahwa brand image atau citra merek merupakan suatu asosiasi/persepsi yang muncul dalam benak konsumen ketika mengingat suatu merek tertentu. Asosiasi tersebut dapat dikonseptualisasikan berdasarkan jenis, dukungan, kekuatan, dan keunikan. Jenis asosiasi tersebut meliputi atribut, manfaat dan sikap (Shimp, 2003).

Sutisna dan Prawita (2001) menjelaskan bahwa manfaat brand image adalah sebagai berikut:

1) Konsumen dengan citra yang positif terhadap suatu merek, lebih mungkin untuk melakukan pembelian,

2) Perusahaan dapat mengembangkan lini produk dengan memanfaatkan citra positif yang telah terbentuk terhadap merek produk lama, dan

3) Kebijakan family branding dan leverage branding dapat dilakukan jika citra produk yang telah ada positif.

Schiffman dan Kanuk (2007) menyebutkan faktor-faktor pembentuk citra merek adalah sebagai berikut :

1) Kualitas atau mutu, berkaitan dengan kualitas produk barang dan jasa yang ditawarkan oleh produsen,

2) Dapat dipercaya atau diandalkan, berkaitan dengan pendapat atau kesepakatan yang dibentuk oleh masyarakat tentang suatu produk atau jasa yang dikonsumsi,

3) Kegunaan atau manfaat yang terkait dengan fungsi dari suatu produk atau jasa yang bisa dimanfaatkan oleh konsumen,

4) Pelayanan, yang berkaitan dengan tugas produsen dalam melayani konsumen,

5) Risiko, berkaitan dengan besar kecilnya akibat atau untung rugi yang mungkin dialami oleh konsumen,

6) Harga, yang dalam hal ini berkaitan dengan tinggi rendahnya atau banyak sedikitnya jumlah biaya yang dikeluarkan konsumen untuk menempuh studi,

7) Citra yang dimiliki oleh merek itu sendiri, yaitu berupa pandangan, kesepakatan, dan informasi yang berkaitan dengan suatu merek tertentu.

Menurut Biels (1992) yang dikutip oleh Sutisna (2001), Citra merek memiliki 3 (tiga) variabel pendukung, yaitu: 
1) Citra perusahaan (corporate image), yaitu sekumpulan asosiasi yang dipersepsikan konsumen terhadap perusahaan yang membuat suatu produk atau jasa. Dalam penelitian ini citra pembuat meliputi: popularitas, kredibilitas serta jaringan perusahaan,

2) Citra pemakai (user image), yaitu sekumpulan asosiasi yang dipersepsikan konsumen terhadap pemakai yang menggunakan suatu barang atau jasa. Meliputi : pemakai itu sendiri, gaya hidup/kepribadian, serta status sosialnya,

3) Citra Produk (product image), yaitu sekumpulan asosiasi yang dipersepsikan konsumen terhadap suatu produk. Meliputi artibut produk tersebut, manfaat bagi konsumen, penggunanya, serta jaminan.

Dari beberapa pengertian tersebut dapat diketahui bahwa citra merek merupakan aspek yang cukup menjadi pertimbangan konsumen dalam melakukan pembelian.

Menurut Keller (2003), di dalam brand image terdapat 3 faktor yang merangkai sebuah brand image, antara lain :

a Brand Favorability adalah kesukaan terhadap brand, kepercayaan dan perasaan bersahabat dengan suatu brand, serta akan sulit bagi brand, lain untuk dapat menarik konsumen yang sudah mencintai brand, hingga pada tahap ini. Indikator dari Brand Favorability meliputi:

1. Popularitas

2. Kredibilitas

b Brand Strength adalah seberapa sering seseorang terpikir tentang informasi suatu brand, ataupun kualitas dalam memproses segala informasi yang diterima konsumen. Indikator dari Brand Strength meliputi:

1. Nilai perusahaan

2. Atribut

c Brand Uniqueness adalah membuat kesan unik dan perbedaan yang berarti diantara brand lain serta membuat konsumen tidak mempunyai alasan untuk tidak memilih brand tersebut. Indikator dari Brand Uniqueness meliputi:

1. Kemudahan mendapatkan produk yang dibutuhkan

2. Penawaran varian paket

\section{Biaya Pendidikan}

Definisi biaya menurut Supriyono (2000) biaya adalah pengorbanan ekonomis yang dibuat untuk memperoleh barang atau jasa. Secara bahasa, biaya (cost) dapat diartikan sebagai pengeluaran, dalam istilah ekonomi biaya/pengeluaran dapat berupa uang atau bentuk moneter lainnya (Ardiansyah dalam Kabar Pendidikan). Sedangkan biaya pendidikan menurut Supriadi (2007), merupakan salah satu komponen instrumental (instrumental input) yang sangat penting dalam penyelenggaraan pendidikan. Biaya dalam pengertian ini memiliki cakupan yang luas, yakni semua jenis pengeluaran yang berkenaan dengan penyelenggaraan pendidikan, baik dalam bentuk uang maupun barang dan tenaga (yang dapat dihargakan uang).

Konsumen lebih mementingkan manfaat dan citra yang didapat dari setiap rupiah yang dikeluarkannya. Penentuan produk jasa dapat dikaitkan dengan konsep net value, semakin besar manfaat yang dirasakan dibanding biaya yang dikeluarkan akan dinilai konsumen sebagai positif value.

Biaya pendidikan merupakan salah satu komponen masukan instrumental yang sangat penting dalam penyelenggaraan pendidikan. Dapat dikatakan bahwa proses pendidikan tidak akan dapat berjalan tanpa dukungan biaya.

Dari segi pengaturan keuangan, sumber pendapatan dan pembiayaan perguruan tinggi negeri berasal dari dukungan dana (block grant) pemerintah, SPP, royalti, dan dividen dari usaha/kontrak dan layanan yang diselenggarakan PTN, sponsor penelitian, dan lain-lain (Lupiyoadi dan Hamdani, 2006). 
Ada beberapa komponen dalam biaya pendidikan menurut Abdullah N.S. (dalam Sofa, 2008), yaitu meliputi:

1. Peningkatan kegiatan belajar mengajar;

2. Pemeliharaan dan penggantian sarana dan prasarana pendidikan;

3. Peningkatan pembinaan kegiatan mahasiswa;

4. Kesejahteraan;

5. Rumah tangga universitas; dan

6. Biaya pembinaan, pemantauan, pengawasan dan pelaporan.

Menurut Lupiyoadi dan Hamdani (2006), perguruan tinggi menggunakan penentuan biaya perkuliahan yang berbeda untuk tiap mahasiswa dan program, antara lain:

1. Berdasarkan program studi; contoh: ekonomi, teknik, bahasa, hukum.

2. Berdasarkan tingkatan mahasiswa; contoh: mahasiswa S1 berbeda pascasarjana, dimana biaya untuk pascasarjana lebih mahal.

3. Berdasarkan beban kredit mahasiswa

4. Berdasarkan jenis program mahasiswa; contoh: program dengan gelar (S1) atau nongelar/sarjana muda/diploma

5. Berdasarkan waktu dan tempat perkuliahan; contoh: kelas malam hari berbeda biayanya dengan kelas reguler di siang hari

Dalam penelitian ini, biaya pendidikan adalah keseluruhan pengorbanan finansial yang dikeluarkan oleh konsumen (orangtua mahasiswa atau mahasiswa) untuk keperluan selama menempuh pendidikan dari awal sampai berakhirnya pendidikan. Baik itu biaya registrasi dan sks tiap semester, biaya sumbangan pembangunan gedung, dana kesejahteraan dan fasilitas mahasiswa (DKFM) per semester, dan biaya-biaya perkuliahan lainnya yang meliputi biaya pengembangan dan pembiayaan kegiatan kurikuler dan ekstra kurikuler, biaya buku peralatan, biaya ujian negara, serta biaya-biaya pendidikan lainnya yang digunakan untuk menunjang perkuliahan (Lupiyoadi dan Hamdani,2006).

Dalam kondisi krisis ekonomi saat ini, dimana terjadi penurunan kemampuan daya beli masyarakat menyebabkan konsumen menjadi peka akan masalah biaya. Perguruan tinggi harusnya semakin hati-hati dalam menetapkan biaya pendidikannya. Agar nantinya biaya yang harus ditanggung mahasiswa tidaklah berat dan sesuai dengan kemampuan atau daya beli mereka.

\section{Keputusan Pembelian Konsumen}

Konsumen memperlakukan pengambilan keputusan sebagai suatu pemecahan masalah, dengan asumsi bahwa konsumen memiliki sasaran (konsekuensi yang diinginkan atau nilai dalam rantai arti-akhir) yang ingin dicapai atau dipuaskan. Seorang konsumen menganggap sesuatu adalah "masalah" karena konsekuensi yang diinginkannya belum dapat dicapai. Konsumen membuat keputusan perilaku mana yang ingin dilakukan untuk dapat mencapai sasaran mereka, dan dengan demikian memecahkan masalahnya. Dalam pengertian ini, pengambilan keputusan konsumen adalah proses pemecahan masalah yang diarahkan pada sasaran (Peter dan Olson,2000).

Proses pemecahan masalah konsumen sangat dipengaruhi oleh jumlah pengetahuan produk yang mereka dapatkan dari sepanjang pengalaman masa lalu mereka, dan melalui tingkat keterlibatan mereka dengan produk dan/atau proses pemilihan. Menurut Bearden et. al. (2001), keterlibatan menggambarkan tingkat kepentingan atau minat yang dihasilkan oleh suatu produk atau keputusan. Keterlibatan ini dibedakan oleh situasi atau keputusan produk dan dipengaruhi oleh kebutuhan atau motif pribadi. Sering kali, keterlibatan dipengaruhi oleh seberapa erat keputusan pembelian ini terkait dengan konsep diri konsumen dan seberapa relevan produk itu terhadap konsumen.

Perilaku konsumen adalah proses yang terjadi pada konsumen ketika iamemutuskan membeli, apa yang dibeli, di mana dan bagaimana membelinya (Kotler, 
2005). Setiap pembelian konsumen tercipta karena adanya needs (kebutuhan keperluan) atau wants (keinginan) atau campuran keduanya.

Faktor-faktor yang mempengaruhi konsumen dalam pengambilan keputusan membeli:

a Faktor Lingkungan yang terdiri atas: Faktor budaya yang meliputi, Nilai-nilai yaitu norma yang dianut masyarakat, Persepsi yaitu cara pandang sesuatu, Preferensi yaitu rasa suka pada satu produk dibandingkan produk lain, Behaviour yaitu kebiasaan.

b Faktor Sosial meliputi: Faktor ini adalah kelompok yang mempengaruhi anggota/ komunitas dalam membuat keputusan terhadappembelian suatu barang atau jasa. Keluarga Faktor ini adalah juga penting pengaruhnya bagi seseorang dalam memilih suatu barang atau jasa. Peran dan status seseorang di masyarakat atau perusahaan akan mempengaruhi pola tindakannya dalam membeli barang atau jasa.

c Faktor Teknologi yang meliputi: Transportasi pribadi, alat rumah tangga. Audio visual, internet dan seluler.

d Faktor Pribadi dari: 1. Aspek pribadi yaitu seorang konsumen akan berbeda dari seorang konsumen lainnya karena faktor-faktor pribadi dalam hal berikut: usia, pekerjaan, kondisi keuangan, gaya hidup, kepribadian, konsep diri. 2. Aspek psikologis yaitu faktor kejiwaan atau psikologi yang mempengaruhi seseorang dalam tindakan membeli suatu barang/jasa yang terdiri dari: motivasi, persepsi, kepercayaan dan perilaku. Menurut Kotler dan Keller (2007) citra merek adalah persepsi dan keyakinan yang dilakukan oleh konsumen, seperti tercermin dalam asosiasi yang terjadi dalam memori konsumen. Persepsi merupakan aktivitas penting yang menghubungkan konsumen individual dengan kelompok, situasi dan pengaruh pemasar. Menurut Kotler (2007), persepsi merupakan proses bagaimana individu memilih, mengorganisasikan, dan mengintepretasikan masukan-masukan informasi untuk menciptakan gambaran dunia yang memiliki arti. Persepsi meliputi semua proses yang dilakukan seseorang dalam memahami informasi mengenai lingkungannya.

\section{Tingkat Keterlibatan Konsumen}

Tingkat keterlibatan konsumen merupakan determinan yang paling signifikan dalam klasifikasi keputusan pembelian. Keterlibatan (involvement) merupakan jumlah waktu dan upaya yang diperlukan oleh seorang pembeli dalam mencari, evaluasi, dan proses keputusan perilaku konsumen.

Terdapat dua jenis keputusan yang dikaitkan dengan tingkat keterlibatan yaitu keputusan dengan tingkat keterlibatan tinggi (high-involvement decisions) dan keputusan dengan tingkat keterlibatan rendah (low-involvement decisions). High-involvement decisions dicirikan oleh tingkat kepentingan yang tinggi, pemrosesan informasi yang terperinci, dan perbedaan substansial antara alternatif-alternatif. Keterlibatan tinggi dapat disebabkan oleh faktor jumlah orang, produk, dan perubahan. Sedangkan low-involvement decisions terjadi ketika secara relatif sedikit minat pribadi, relevansi, atau kepentingan yang berhubungan dengan pembelian. Keputusan ini melibatkan banyak proses keputusan sederhana, dan sedikit pemrosesan informasi.

Tingkat keterlibatan di dalam keputusan pembelian tergantung pada lima faktor: pengalaman sebelumnya, minat, risiko yang dirasa, situasi, dan pandangan sosial (Lamb, et. al.,2001).

1) Pengalaman sebelumnya (previous experience): ketika para konsumen telah memiliki pengalaman sebelumnya dengan barang atau jasa, tingkat keterlibatan biasanya menurun. 
2) Minat (interest) : keterlibatan berhubungan langsung kepada minat para konsumen, seperti pada mobil, musik, film, bersepeda atau elektronik.

3) Risiko (perceived risk of negative consequences) : seperti risiko yang dirasakan dalam pembelian suatu produk meningkat maka keterlibatan konsumen juga tinggi. Jenis risiko yang membuat konsumen memperhatikan, di dalamnya termasuk risiko keuangan, risiko sosial, dan risiko psikologis.

4) Situasi (situation) : keadaan pembelian akan mengubah keputusan atas keterlibatan yang rendah menjadi keterlibatan yang tinggi. Keterlibatan yang tinggi muncul ketika para konsumen merasakan risiko pada situasi khusus.

5) Pandangan sosial (social visibility) : keterlibatan juga meningkat sebagai pandangan sosial dari meningkatnya produk.

Proses pengambilan keputusan konsumen meliputi serangkaian kegiatan mulai dari pengenalan masalah, pencarian informasi, evaluasi alternatif, keputusan pembelian dan perilaku pasca pembelian.

1. Pengenalan Masalah

Proses pembelian diawali dengan pengenalan masalah atau kebutuhan. Kebutuhan dapat dipicu oleh rangsangan internal ketika salah satu kebutuhan normal seseorang rasa lapar, haus, seks - muncul pada tingkat yang cukup tinggi untuk menjadi dorongan. Suatu kebutuhan juga dapat dipicu oleh rangsangan eksternal. Misalnya, seseorang melewati toko kue dan melihat roti yang segar serta hangat sehingga terangsang rasa laparnya.

2. Pencarian Informasi

Konsumen yang terangsang kebutuhannya akan terdorong untuk mencari informasi yang lebih banyak. Kita dapat membaginya ke dalam dua level rangsangan. Situasi pencarian informasi yang lebih ringan dinamakan penguatan perhatian. Pada level itu orang hanya sekedar lebih peka terhadap informasi produk. Pada level selanjutnya, orang itu mungkin masuk ke pencarian informasi secara aktif. Mencari bahan bacaan, menelepon teman, dan mengunjungi toko untuk mempelajari produk tertentu.

3. Evaluasi Alternatif

Evaluasi alternatif merupakan tahap dalam proses pengambilan keputusan pembeli dimana konsumen menggunakan informasi untuk mengevaluasi merek-merek alternatif dalam satu susunan pilihan.

4. Keputusan Pembelian

Dalam tahap evaluasi, konsumen membuat peringkat atas merek dan membentuk niat untuk membeli. Biasanya, keputusan pembelian konsumen adalah membeli merek yang paling disukai, tetapi dua faktor dapat muncul antara niat untuk membeli dan keputusan pembelian. Faktor pertama adalah sikap orang lain. Faktor kedua adalah faktor situasi yang tidak diharapkan, seperti kehilangan pekerjaan.

5. Perilaku Pasca Pembelian

Perilaku pasca pembelian merupakan tahap dalam proses pengambilan keputusan pembeli dimana konsumen mengambil tindakan lebih lanjut setelah membeli berdasarkan kepuasan atau ketidakpuasan yang mereka rasakan.

\section{Penelitian Terdahulu}

Penelitian terdahulu digunakan oleh penulis sebagai acuan untuk menentukan beberapa hal yang berhubungan dengan teori dan sistematika penelitian ini antara lain:

1. Fitria Engla Sagita (2013), dengan judul penelitian "Pengaruh Brand Image dan Harga Terhadap Keputusan Pembelian Ulang Produk Kentucky Fried Chicken di Cabang Basko Grand Mall Oleh Mahasiswa Universitas Negeri Padang”. Hasil analisis dan pembahasan menunjukkan bahwa brand image dan harga berpengaruh signifikan dengan sig $<0,05$ terhadap keputusan pembelian ulang produk Kentucky Fried Chicken (KFC) di cabang Basko Grand Mall oleh mahasiswa Universitas Negeri Padang. 
Berdasarkan hasil uji regresi berganda hipotesis 1 diterima karena $t$ hit $=2,010>t$ tabel 1,985 dengan $\mathrm{a}=0,05$ atau level sig $0,047<0,005$. Berarti terdapat pengaruh yang signifikan antara brand image terhadap keputusan pembelian ulang produk Kentucky Fried Chicken di cabang Basko Grand Mall oleh mahasiswa Universitas Negeri Padang. Berdasarkan hasil uji regresi berganda hipotesis 2 diterima karena t hit $=2,053$ $>\mathrm{t}$ tabel 1,985 dengan a $=0,05$ atau level sig $0,043<0,005$. Berarti terdapat pengaruh yang signifikan antara harga terhadap keputusan pembelian ulang produk Kentucky Fried Chicken (KFC) di cabang Basko Grand Mall oleh mahasiswa Universitas Negeri Padang.

2. Kurnia Akbar (2013), dengan judul penelitian "Analisis Pengaruh Harga, Brand Image, dan Atribut Produk Terhadap Keputusan Pembelian Handphone atau Smartphone Samsung Jenis Android". Hasil analisis dan pembahasan menunjukkan bahwa harga, brand image, dan atribut produk secara parsial dan simultan berpengaruh signifikan terhadap keputusan pembelian handphone atau smartphone jenis android.

3. Karina Pradityas Putri (2011), dengan judul peneltian "Analisis Pengaruh Brand Image, Biaya Pendidikan, dan Fasilitas Pendidikan Terhadap Keputusan Mahasiswa Melanjutkan Studi Pada Program Diploma III Fakultas Ekonomi Universitas Diponegoro Semarang". Hasil analisis dan pembahasan menunjukkan bahwa brand image, biaya pendidikan, dan fasilitas pendidikan secara parsial dan simultan berpengaruh signifikan terhadap keputusan mahasiswa.

\section{METODE PENELITIAN}

\section{Rancangan Penelitian}

Dalam penelitian ini akan digunakan penelitian konklusif yang mana penelitian ini didesain untuk menolong pengambil keputusan dalam menentukan, mengevaluasi dan memilih alternatif terbaik dalam memecahkan suatu masalah. Adapun tipe penelitian konklusif yang akan digunakan adalah tipe penelitian kausalitas. Penelitian kausalitas adalah penelitian yang ingin mencari penjelasan dalam bentuk hubungan sebab-akibat (cause-effect) dari beberapa variabel atau beberapa strategi yang dikembangkan dalam manajemen (Ferdinand, 2006). Penelitian ini diarahkan untuk menggambarkan adanya hubungan sebab-akibat dari beberapa situasi yang digambarkan dalam variabel, dan atas dasar itu ditariklah sebuah kesimpulan umum.

\section{Unit Analisis Penelitian}

Unit analisis adalah unit yang akan diteliti dan akan dijelaskan serta merupakan obyek penelitian yang dapat berupa individu, perorangan, kelompok, organisasi, masyarakat, hasil karya manusia, instansi dan sebagainya (Kusmayadi dan Sugiarto, 2000). Berkaitan dengan hal tersebut, unit analisis dalam penelitian ini Sekolah Tinggi Ilmu Ekonomi Rahmaniyah (STIER), sedangkan yang menjadi unit observasi adalah mahasiswa baru Program Studi Manajemen tahun akademik 2013/2014.

\section{Populasi dan Sampel}

Populasi adalah wilayah generalisasi yang terdiri atas objek/subjek yang mempunyai kualitas dan karakteristik tertentu yang ditetapkan oleh peneliti untuk dipelajari dan kemudian ditarik kesimpulannya (Sugiyono, 2008). Sedangkan sampel adalah subset dari populasi, terdiri dari beberapa anggota populasi (Ferdinand, 2006). Adapun metode pengambilan sampel dalam penelitian ini menggunakan nonprobability sampling yaitu teknik pengambilan sampel yang tidak memberi peluang/kesempatan sama bagi setiap unsur atau anggota populasi untuk dipilih menjadi sampel (Sugiyono, 2008). 
Teknik yang digunakan adalah accidental sampling. Accidental sampling adalah teknik penentuan sampel berdasarkan kebetulan, yaitu siapa saja yang secara kebetulan/insidental bertemu dengan peneliti dapat digunakan sebagai sampel, bila dipandang orang yang kebetulan ditemui itu cocok sebagai sumber data (Sugiyono, 2008). Dalam penelitian ini yang menjadi populasi adalah mahasiswa baru Program Studi Manajemen tahun akademik 2013/2014.

Berdasarkan data yang diperoleh, jumlah mahasiswa baru Program Studi Manajemen tahun akademik 2013/2014 adalah sebanyak 360 orang. Dengan demikian, berdasarkan rumus Slovin maka jumlah mahasiswa baru yang akan diambil sebagai sampel dengan margin of error $10 \%$ adalah sebanyak 79 orang.

Rumus Slovin

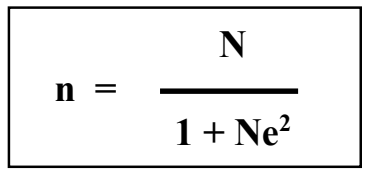

dimana :

$\mathrm{n}=$ ukuran sampel

$\mathrm{N}=$ ukuran populasi

$\mathrm{e}=$ persen kelonggaran ketidaktelitian yang masih dapat ditolerir

Jadi perhitungannya adalah sebagai berikut:

$$
\begin{aligned}
& \mathrm{n}=\frac{360}{1+360(0,10)^{2}} \\
& \mathrm{n}=\frac{360}{1+360(0,010)}=\frac{360}{4,6} \\
& \mathrm{n}=78,261=79 \text { orang (dibulatkan) }
\end{aligned}
$$

\section{Variabel Penelitian}

\section{a. Identifikasi Variabel}

Variabel-variabel yang dianalisis dalam penelitian ini meliputi variabel bebas (independent variable) yaitu variabel $\mathrm{X}$ dan variabel terikat (dependent variable) yaitu variabel Y. Variabel bebas (independent variable) merupakan variabel yang mempengaruhi atau menjadi sebab perubahannya atau timbulnya variabel terikat (dependent variable) (Sugiyono,2008). Sedangkan variabel terikat (dependent variable) merupakan variabel yang dipengaruhi atau yang menjadi akibat, karena adanya variabel bebas (independent variable) (Sugiyono,2008). Variabel $\mathrm{X}$ dalam penelitian ini adalah brand image (X1) dan biaya pendidikan (X2), sedangkan variabel Y adalah keputusan mahasiswa untuk memilih Program Studi Manajemen. Variabel-variabel tersebut diformulasikan sebagai berikut :

$$
\text { dimana : }
$$

$$
\mathbf{Y}=\mathbf{a}+\mathbf{b} 1 \mathbf{X} 1+\mathbf{b} 2 \mathbf{X} 2
$$

$\mathrm{Y}=$ Keputusan Mahasiswa Untuk Memilih Program Studi Manajemen

$\mathrm{X}_{1}=$ Brand Image

$\mathrm{X}_{2}=$ Biaya Pendidikan 


\section{b. Operasionalisasi Variabel}

Guna mempermudah pemberian arah dan memberi kejelasan tentang variabel penelitian ini maka penting untuk mendefinisikan terlebih dahulu konsep dan operasional dari masing-masing variabel yaitu variabel brand image, variabel kelompok referensi, dan variabel keputusan mahasiswa untuk memillih Program Studi Manajemen. Setiap variabel terdiri dari beberapa indikator yang akan digunakan untuk mengukur sejauh mana variabelvariabel tersebut memberikan pengaruh yang signifikan terhadap keputusan mahasiswa untuk memilih Program Studi Manajemen.

Indikator-indikator yang digunakan pada penelitian ini merujuk pada indikatorindikator yang telah digunakan pada penelitian-penelitian terdahulu. Indikator-indikator tersebut seperti terdapat pada tabel 1 dan telah disesuaikan agar dapat digunakan dalam penelitian lebih lanjut.

Tabel 1

Operasionalisasi Variabel

\begin{tabular}{|c|c|c|}
\hline VARIABEL & DIMENSI & INDIKATOR \\
\hline \multirow{3}{*}{$\begin{array}{l}\text { Brand Image } \\
\text { (X1) }\end{array}$} & $\begin{array}{l}\text { Citra } \\
\text { Perusahaan }\end{array}$ & $\begin{array}{ll}\text { - } & \text { Reputasi sekolah } \\
\text { - } & \text { Popularitas sekolah } \\
\text { - } & \text { Kredibilitas sekolah } \\
\text { - } & \text { Tenaga pengajar yang profesional } \\
\end{array}$ \\
\hline & $\begin{array}{l}\text { Citra } \\
\text { Konsumen }\end{array}$ & $\begin{array}{ll} & \text { Prestisius } \\
\text { - } & \text { Kepercayaan } \\
\text { - } & \text { Kenyamanan } \\
& \text { sejawat } \\
\end{array}$ \\
\hline & Citra Produk & $\begin{array}{ll}\text { - } & \text { Layanan yang berkualitas } \\
\text { - } & \text { Sarana dan prasarana yang memadai } \\
\text { - } & \text { Lulusan yang berkompeten } \\
\end{array}$ \\
\hline $\begin{array}{l}\text { Biaya Pendidikan } \\
\text { (X2) }\end{array}$ & & $\begin{array}{ll}\text { - } & \text { Terjangkaunya biaya pendidikan } \\
\text { - Kesesuaian biaya dengan kualitas layanan } \\
\text { - Kesesuaian biaya dengan manfaat yang } \\
\text { diperoleh } \\
\text { - Tersedianya beasiswa pendidikan } \\
\end{array}$ \\
\hline $\begin{array}{l}\text { Keputusan } \\
\text { Mahasiswa (Y) }\end{array}$ & & $\begin{array}{l}\text { - } \quad \text { Prioritas pilihan } \\
\text { - } \text { Informasi yang lengkap dan terpercaya } \\
\text { - } \quad \text { Keyakinan terhadap pilihan } \\
\text { - Sesuai kebutuhan }\end{array}$ \\
\hline
\end{tabular}

\section{Pengukuran Variabel}

Indikator-indikator dari masing-masing variabel dalam penelitian ini akan diukur dengan menggunakan skala Likert. Skala Likert dirancang untuk menilai sejauh mana responden setuju atau tidak setuju dengan pernyataan yang diajukan. Skala Likert digunakan untuk mengukur respon subjek ke dalam 5 poin skala dengan interval yang sama (Puspowarsito, 2008). Jadi, indikator-indikator dalam penelitian ini akan diukur dengan menggunakan skala Likert 5 tingkat dengan kriteria : (1) Sangat Tidak Setuju (STS), (2) Tidak Setuju (TS), (3) Netral (N), (4) Setuju (S), dan (5) Sangat Setuju (SS). 


\section{Instrumen Penelitian}

\section{a. Kuesioner}

Instrumen atau alat ukur utama yang akan digunakan untuk mengumpulkan data pimer dalam penelitian ini adalah kuesioner. Kuesioner, apakah itu disebut jadwal, bentuk wawancara, atau alat ukur, adalah seperangkat pertanyaan formal untuk memperoleh informasi dari responden (Malhotra, 1999).

\section{b. Uji Validitas}

Uji validitas adalah untuk mengetahui tingkat kevalidan dari instrumen kuesioner yang digunakan dalam pengumpulan data. Uji validitas ini dilakukan untuk mengetahui apakah item-item yang tersaji dalam kuesioner benar-benar mampu mengungkapkan dengan tepat apa yang akan diteliti.

Salah satu cara untuk menghitung validitas instrumen yaitu dengan melihat daya pembeda item (item discriminality). Daya pembeda item adalah metode yang paling tepat digunakan untuk setiap jenis test. Daya pembeda item dalam penelitian ini dilakukan dengan cara "korelasi item-total".

Korelasi item-total yaitu konsistensi antara skor item dengan skor secara keseluruhan yang dapat dilihat dari besarnya koefisien korelasi antara setiap item dengan skor keseluruhan, yang dalam penelitian ini menggunakan koefisien korelasi RankSpearman karena skala pengukuran dalam penelitian ini adalah skala ordinal.

Adapun langkah-langkah melakukan uji validitas adalah:

1. Tentukan koefesien korelasi Rank Spearman dengan cara sebagai berikut:

Apabila item yang dihadapi berbentuk skala ordinal (skala sikap), maka nilai korelasi rank spearman pada item ke-i adalah :

$$
r_{s}=1-\frac{6 \sum d_{i}^{2}}{n(n-1)}
$$

2. Bandingkan nilai koefesien korelasi rank spearman (rs) dengan nilai korelasi rank spearman dalam table ( $\mathrm{r}$ tabel), atau bandingkan nilai p-value (Sig.) pada koefesien korelasi rank spearman (rs) dengan taraf nyata $(\alpha)$.

3. Jika rs $>r$ tabel atau $p$-value $<\alpha$, maka item tersebut valid dan dapat dijadikan sebagai indikator terhadap dimensi/variabel tersebut.

\section{c. Uji Reliabilitas}

Uji reliabilitas artinya adalah tingkat keterpercayaan hasil suatu pengukuran. Pengukuran yang memiliki reliabilitas tinggi, yaitu pengukuran yang mampu memberikan hasil ukur yang terpercaya (reliabel). Reliabilitas merupakan salah satu ciri atau karakter utama intrumen pengukuran yang baik. Kadang-kadang reliabilitas disebut juga sebagai keterpercayaan, keterandalan, keajegan, konsistensi, kestabilan, dan sebagainya, namun ide pokok dalam konsep reliabilitas adalah sejauh mana hasil suatu pengukuran dapat dipercaya, artinya sejauh mana skor hasil pengukuran terbebas dari kekeliruan pengukuran (measurement error).

Tinggi rendahnya reliabilitas, secara empiris ditunjukkan oleh suatu angka yang disebut koefisien reliabilitas. Rumusan yang digunakan dalam penelitian ini adalah rumus Cronbach Alpha yaitu:

$$
R_{\alpha}=\left(\frac{k}{k-1}\right)\left(1-\frac{\sum \sigma_{b}^{2}}{\sigma_{t}^{2}}\right) \times 100 \%
$$




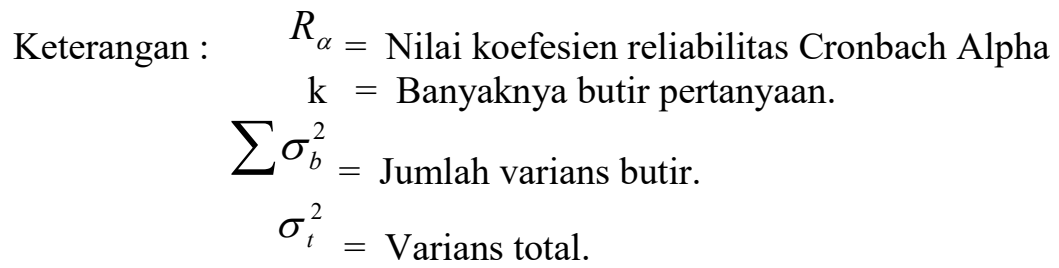

Sedangkan nilai varians sendiri dihitung dengan rumusan:

$$
\begin{array}{cl}
\sigma^{2}= & \frac{\sum X^{2}-\frac{\left(\sum X\right)^{2}}{n}}{n-1} \\
\text { Keterangan : } \quad \begin{aligned}
\sigma^{2} & =\text { Nilai Varians } \\
X & =\text { Nilai-nilai datanya } \\
n & =\text { Jumlah responden }
\end{aligned}
\end{array}
$$

\section{Teknik Analisis Data}

Menurut Aunuddin (Puspowarsito, 2008), proses analisis data pada dasarnya meliputi upaya penelusuran dan pengungkapan informasi yang relevan yang terkandung dalam data dan penyajian hasilnya dalam bentuk yang lebih ringkas dan sederhana, yang pada akhirnya mengarah kepada keperluan adanya penelusuran dan penafsiran. Analisis data bertujuan untuk menjawab pertanyaan, membuktikan hipotesis, dan atau menjelaskan fenomena yang menjadi latar belakang penelitian.

Dalam penelitian ini, teknik analisis data yang akan digunakan adalah analisis faktor, analisis cluster dan analisis regresi. Proses pengolahan data dilakukan dengan bantuan program SPSS for Windows.

\section{a. Analisis Regresi}

Analisis regresi merupakan salah satu metode statistika yang digunakan untuk menjelaskan hubungan fungsional antara variabel yang dinyatakan dalam suatu model atau persamaan. Model regresi sebagai alat untuk menerangkan, memahami, mengendalikan, dan memprediksikan hubungan antara variabel yang diteliti.

\section{b. Analisis Korelasi}

Analisis korelasi adalah metode statistik yang digunakan untuk mengukur besarnya hubungan linier antara dua variabel atau lebih. Jika korelasi bernilai positif maka hubungan antara dua variabel bersifat searah. Sebaliknya jika korelasi bernilai negatif maka hubungan antara dua variabel bersifat berlawanan arah.

\section{c. Koefisien Determinasi (Uji $\mathbf{R}^{2}$ )}

$\mathrm{Uji} \mathrm{R}^{2}$ atau uji determinasi merupakan suatu ukuran yang penting dalam regresi, karena dapat menginformasikan baik atau tidaknya model regresi yang terestimasi. Nilai koefisien determinasi $\left(\mathrm{R}^{2}\right)$ ini mencerminkan seberapa besar variasi dari variabel terikat $\mathrm{Y}$ dapat diterangkan oleh variabel bebas $X$. Bila nilai koefisien determinasi sama dengan 0 $\left(\mathrm{R}^{2}=0\right)$, artinya variasi dari $\mathrm{Y}$ tidak dapat diterangkan oleh $\mathrm{X}$ sama sekali. Sementara bila $\mathrm{R}^{2}=1$, artinya variasi dari $\mathrm{Y}$ secara keseluruhan dapat diterangkan oleh $\mathrm{X}$. Dengan kata lain bila $\mathrm{R}^{2}=1$, maka semua titik pengamatan berada tepat pada garis regresi. Dengan demikian baik atau buruknya suatu persamaan regresi ditentukan oleh $\mathrm{R}^{2}$ nya yang mempunyai nilai antara nol dan satu.

\section{d. Uji Hipotesis (Uji t dan Uji F)}


Uji t digunakan untuk menguji secara parsial masing-masing variabel. Hasil uji t dapat dilihat pada tabel coefficients pada kolom sig (significance). Jika probabilitas nilai t atau signifikansi $<0,05$, maka dapat dikatakan bahwa terdapat pengaruh antara variabel bebas terhadap variabel terikat secara parsial.

Sedangkan uji $\mathrm{F}$ digunakan untuk mengetahui pengaruh variabel bebas secara bersama-sama (simultan) terhadap variabel terikat. Signifikan berarti hubungan yang terjadi dapat berlaku untuk populasi. Hasil uji $\mathrm{F}$ dilihat dalam tabel ANOVA dalam kolom sig. Sebagai contoh, kita menggunakan taraf signifikansi $5 \%(0,05)$, jika nilai probabilitas $<0,05$, maka dapat dikatakan terdapat pengaruh yang signifikan secara bersama-sama antara variabel bebas terhadap variabel terikat.

\section{HASIL DAN PEMBAHASAN}

\section{Analisis Regresi Linier Berganda}

Analisis regresi linier berganda dilakukan ketika terdapat dua atau lebih variabel independen $(\mathrm{X})$ yang berpengaruh terhadap variabel dependen $(\mathrm{Y})$. Berdasarkan analisis regresi linier berganda pengaruh brand image dan biaya pendidikan terhadap keputusan mahasiswa dalam memilih program studi manajemen di STIE Rahmaniyah Sekayu, maka diperoleh hasil sebagai berikut.

Tabel 2

\section{Coefficients}

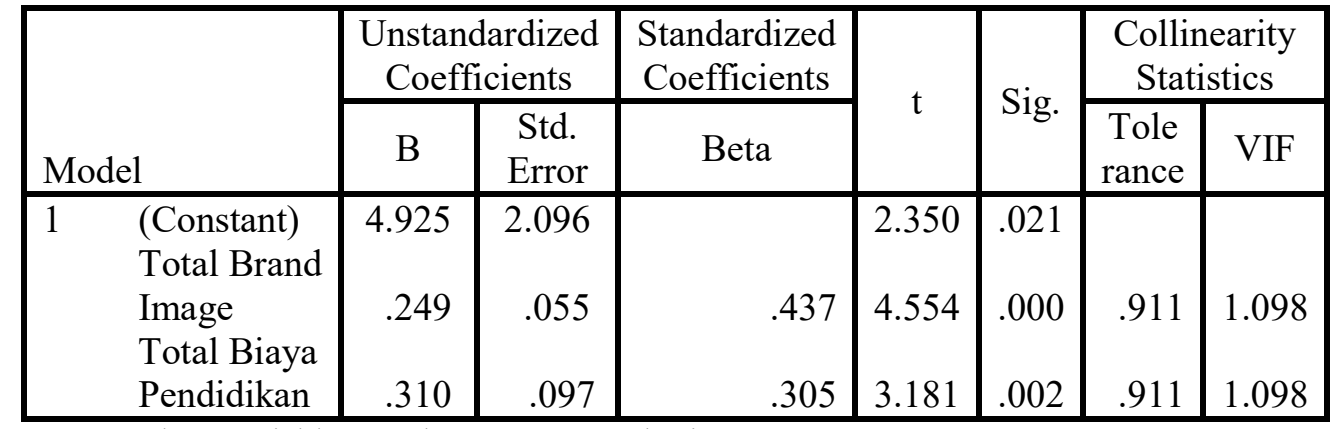

a. Dependent Variable: Total Keputusan Mahasiswa

Berdasarkan hasil analisis regresi linier pada tabel 2 di atas, persamaan regresi yang dibentuk adalah: $\mathbf{Y}=\mathbf{4 , 9 2 5}+\mathbf{0 , 2 4 9 X 1}+\mathbf{0 , 3 1 0 X 2}+\mathbf{e}$. Persamaan regresi linier tersebut menggambarkan bahwa:

a. Nilai konstanta sebesar 4,925; artinya jika variabel brand image dan biaya pendidikan adalah nol, maka keputusan mahasiswa (Y) adalah sebesar 4,925.

b. Variabel brand image (X1) mempunyai nilai koefisien regresi sebesar 0,249 yang berarti brand image mempunyai pengaruh positif terhadap keputusan mahasiswa. Dengan kata lain jika brand image ditingkatkan 1 satuan maka keputusan mahasiswa akan bertambah sebesar 0,249

c. Variabel biaya pendidikan (X2) mempunyai nilai koefisien regresi sebesar 0,310 yang berarti biaya pendidikan mempunyai pengaruh positif terhadap keputusan mahasiswa untuk memilih Program Studi Manajemen di STIE Rahmaniyah Sekayu. Artinya meskipun terjadi kenaikan biaya pendidikan, mahasiswa masih akan memilih STIE Rahmaniyah karena terjangkaunya biaya pendidikan, kesesuaian biaya dengan kualitas layanan, kesesuaian biaya dengan manfaat yang diperoleh, dan tersedianya beasiswa pendidikan. 


\section{Analisis Korelasi}

\section{Tabel 3}

Model Summary

\begin{tabular}{|l|r|r|r|r|r|}
\hline Model & $\mathrm{R}$ & $\mathrm{R}$ Square & $\begin{array}{c}\text { Adjusted } \\
\mathrm{R} \text { Square }\end{array}$ & $\begin{array}{c}\text { Std. Error of } \\
\text { the Estimate }\end{array}$ & $\begin{array}{c}\text { Durbin- } \\
\text { Watson }\end{array}$ \\
\hline 1 & $.603^{\mathrm{a}}$ & .363 & .347 & 2.004 & 1.795 \\
\hline
\end{tabular}

a. Predictors: (Constant), Total Biaya Pendidikan, Total Brand Image

b. Dependent Variable: Total Keputus an Mahasiswa

Tabel 3 di atas menunjukkan bahwa koefisien korelasi (R) adalah sebesar 0,603. Hal ini berarti hubungan antara brand image dan biaya pendidikan dengan keputusan mahasiswa bersifat signifikan karena nilai koefisien korelasi (R) mendekati 1.

\section{Koefisien Determinasi}

Tabel 3 juga memperlihatkan nilai koefisien determinasi (R Square) yang digunakan untuk mengetahui persentase pengaruh variabel independen $(X)$ terhadap variabel dependen (Y). Nilai R Square sebesar 0,363 menunjukkan bahwa keputusan mahasiswa dipengaruhi oleh variabel brand image dan biaya pendidikan hanya sebesar $36,3 \%$, sedangkan sisanya sebesar $63,7 \%$ dipenaruhi oleh faktor-faktor lain yang tidak diteliti.

\section{Uji t dan Uji F}

Untuk uji signifikansi pengaruh brand image dan biaya pendidikan terhadap keputusan mahasiswa dalam memilih Program Studi Manajemen di STIE Rahmaniyah Sekayu digunakan uji t (uji student) atau uji parsial dan uji F (uji Fisher) atau uji simultan. Sampel yang digunakan sebanyak 79 orang, sehingga pengujian menggunakan uji $\mathrm{T}$ dengan $\mathrm{df}=77$ dan tingkat signifikansi $(\alpha)=5 \%$, maka diperoleh $\mathrm{T}_{\text {tabel }}$ sebesar 1,991 . Dengan kriteria pengujian :

- Jika $\mathrm{T}_{\text {hitung }}>\mathrm{T}_{\text {tabel, }}$ maka variabel $\mathrm{X}$ mempunyai hubungan yang erat dan signifikan dengan variabel $\mathrm{Y}$.

- Jika $\mathrm{T}_{\text {hitung }}<\mathrm{T}_{\text {tabel, }}$ maka variabel $\mathrm{X}$ tidak mempunyai hubungan yang erat dan signifikan dengan variabel $\mathrm{Y}$.

Berdasarkan pada tabel 2 dapat dilihat bahwa $T_{\text {hitung }}$ untuk variabel brand image sebesar 4,554 lebih besar dari $T_{\text {tabel }}$ sebesar 1,991. Begitu juga dengan $T_{\text {hitung }}$ untuk variabel biaya pendidikan sebesar 3,181 lebih besar dari $\mathrm{T}_{\text {tabel }}$ sebesar 1,991. Sehingga dapat disimpulkan bahwa terdapat pengaruh antara brand image dan biaya pendidikan terhadap keputusan mahasiswa, dan yang paling berpengaruh adalah variabel brand image.

Berikutnya adalah hasil uji F yang dapat dilihat pada tabel berikut :

\section{Tabel 4}

ANOVA

\begin{tabular}{|c|c|c|c|c|c|c|}
\hline Model & & $\begin{array}{l}\text { Sum of } \\
\text { Squares }\end{array}$ & $\mathrm{df}$ & Mean Square & $F$ & Sig. \\
\hline \multirow[t]{3}{*}{1} & Regression & 174.355 & 2 & 87.177 & 21.697 & $.000^{a}$ \\
\hline & Residual & 305.367 & 76 & 4.018 & & \\
\hline & Total & 479.722 & 78 & & & \\
\hline
\end{tabular}

a. Predictors: (Constant), Total Biaya Pendidikan, Total Brand Image

b. Dependent Variable: Total Keputusan Mahasiswa

Tabel 4 di atas menunjukkan hasil uji $\mathrm{F}$ bahwa nilai $\mathrm{F}_{\text {hitung }}=21,697$ lebih besar dari $\mathrm{F}_{\text {tabel }}=$ 3,12 . Oleh karena itu dapat disimpulkan bahwa variabel brand image dan biaya pendidikan 
berpengaruh secara signifikan terhadap keputusan mahasiswa untuk memilih Program Studi Manajemen di STIE Rahmaniyah.

\section{PEMBAHASAN HASIL PENELITIAN}

Melalui uji analisis regresi, analisis korelasi, uji koefisien determinasi, serta uji hipotesis, diperoleh hasil bahwa brand image dan biaya pendidikan berpengaruh terhadap keputusan mahasiswa dalam memilih Program Studi Manajemen di STIE Rahmaniyah Sekayu. Hal ini sejalan dengan hasil penelitian yang dilakukan oleh Sagita (2013) tentang pengaruh brand image dan harga terhadap keputusan pembelian ulang produk Kentucky Fried Chicken (KFC) di Cabang Basko Grand Mall oleh mahasiswa Universitas Negeri Padang. Penelitian Sagita tersebut menunjukkan hasil bahwa brand image dan harga berpengaruh signifikan terhadap keputusan pembelian ulang produk Kentucky Fried Chicken di Cabang Basko Grand Mall oleh mahasiswa Universitas Negeri Padang.

Dalam penelitian yang dilakukan oleh penulis ditemukan bahwa variabel brand image yang diwakili oleh indikator citra perusahaan, citra konsumen, dan citra produk mempunyai nilai koefisien regresi sebesar 0,249 yang berarti brand image mempunyai pengaruh positif terhadap keputusan mahasiswa. Begitu juga dengan variabel biaya pendidikan yang diwakili oleh indikator terjangkaunya biaya pendidikan, kesesuaian biaya dengan kualitas layanan, kesesuaian biaya dengan manfaat yang diperoleh, dan tersedianya beasiswa pendidikan mempunyai nilai koefisien regresi sebesar 0,310 yang berarti biaya pendidikan mempunyai pengaruh positif terhadap keputusan mahasiswa untuk memilih Program Studi Manajemen di STIE Rahmaniyah Sekayu.

\section{SIMPULAN DAN SARAN}

\section{Simpulan}

Berdasarkan hasil uji analisis regresi berganda dapat ditarik kesimpulan bahwa variabel brand image (X1) dan variabel biaya pendidikan (X2) mempunyai pengaruh positif terhadap keputusan mahasiswa dalam memilih Program Studi Manajemen di STIE Rahmaniyah Sekayu. Dimana variabel brand image (X1) mempunyai nilai koefisien regresi sebesar 0,249 dan variabel biaya pendidikan (X2) mempunyai nilai koefisien regresi sebesar 0,310. Sedangkan hasil uji analisis korelasi menunjukkan bahwa koefisien korelasi (R) adalah sebesar 0,603. Hal ini berarti hubungan antara brand image dan biaya pendidikan dengan keputusan mahasiswa bersifat signifikan karena nilai koefisien korelasi (R) mendekati 1. Sementara hasil uji t menunjukkan bahwa $\mathrm{T}_{\text {hitung }}$ untuk variabel brand image sebesar 4,554 lebih besar dari $\mathrm{T}_{\text {tabel }}$ sebesar 1,991. Begitu juga dengan $\mathrm{T}_{\text {hitung }}$ untuk variabel biaya pendidikan sebesar 3,181 lebih besar dari $\mathrm{T}_{\text {tabel }}$ sebesar 1,991. Sehingga dapat disimpulkan bahwa terdapat pengaruh antara brand image dan biaya pendidikan terhadap keputusan mahasiswa, dan yang paling berpengaruh adalah variabel

brand image.

\section{Saran}

Dengan demikian, berdasarkan hasil analisis tersebut penulis menyarankan kepada pihak pengelola STIE Rahmaniyah Sekayu: (1) untuk selalu memperhatikan apa yang menjadi kepentingan sekolah dan mahasiswa, terutama yang berhubungan dengan segala sarana dan prasarana yang menunjang kegiatan belajar mengajar, serta kualitas pelayanan terutama pelayanan akademik, (2) hendaknya dapat mengaplikasikan apa yang menjadi visi dan misi sekolah, sehingga harapan untuk menghasilkan lulusan yang kompeten dan berkualitas dapat terwujud, (3) dapat meningkatkan kualitas diri melalui pembinaanpembinaan terhadap setiap unsur yang ada di sekolah. 


\section{DAFTAR PUSTAKA}

Akbar, Kurnia. 2013. Analisis Pengaruh Harga, Brand Image, dan Atribut Produk Terhadap Keputusan Pembelian Handphone Atau Smartphone Samsung Jenis Android,Skripsi,UniversitasDiponegoro,http://eprints.undip.ac.id/39672/1/AKBA R.pdf. Diakses: 28 Juni 2013.

Bearden, Bill, Tom Ingram, Buddy LaForge. 2001. Marketing. Principles \& Perspectives, $3^{\text {th }}$ ed, McGraw Hill, New York.

Ferdinand, Augusty. 2006. Metode Penelitian Manajemen. Pedoman Penelitian Untuk Penulisan Skripsi, Tesis dan Disertasi Ilmu Manajemen, Badan Penerbit Universitase Diponegoro, Semarang.

Keller, K. L. 2003. Strategic Brand Management: Intl ed. Building, Measuring, and Managing Brand Equity 2nd ed. New Jersey : Pearson Education, Inc.

Kotler, Philip. 2001. Manajemen Pemasaran di Indonesia: Analisis, Perencanaan, Implementasi dan Pengendalian, Buku 1, Penerbit Salemba Empat, Jakarta.

------------. 2005. Manajemen Pemasaran, Jilid I, Penerbit Indeks, Jakarta.

Kotler, Philip, dan Gery Amstrong. 2012. Prinsip-Prinsip Pemasaran. Edisi 13. Jilid 1. Jakarta: Erlangga.

Kotler, Philip dan Kevin Lane Keller. 2007. Manajemen Pemasaran, Penerbit Erlangga, Jakarta.

2009. Manajemen Pemasaran, Penerbit Erlangga, Jakarta.

Kusmayadi dan Sugiarto. 2000. Metodologi Penelitian dalam bidang Kepariwisataaan, Penerbit Gramedia Pustaka Utama, Jakarta.

Lamb, Jr., Charles W., Joseph F. Hair, Jr., Carl McDaniel. 2001. Pemasaran (Marketing), Buku 1, Penerbit Salemba Empat, Jakarta.

Lupiyoadi, Rambat. 2001. Manajemen Pemasaran Jasa: Teori dan Praktik, Penerbit Salemba Empat, Jakarta.

Lupiyoadi, Rambat dan A. Hamdani. 2006. Manajemen Pemasaran Jasa, Penerbit Salemba Empat, Jakarta.

Malhotra, Naresh K. 1999. Marketing Research. An Applied Orientation, 3rd ed, PrenticeHall, Inc., New Jersey.

Peter, J. Paul, \& Jerry C. Olson. 2000. Consumer Behavior. Perilaku Konsumen dan Strategi Pemasaran, Jilid 1, Penerbit Erlangga, Jakarta.

Puspowarsito, H. A. H. 2008. Metode Penelitian Organisasi dengan Aplikasi Program SPSS, Penerbit Humaniora, Bandung.

Putri, Karina Pradityas. 2011. Analisis Pengaruh Brand Image, Biaya Pendidikan, dan Fasilitas Pendidikan Terhadap Keputusan Mahasiswa Melanjutkan Studi Pada Program Diploma III Fakultas Ekonomi Universitas Diponegoro Semarang, Skripsi,Universitas,Diponegoro.Http://eprints.undip.ac.id/30905/1/Skripsi008.pdf . Diakses: 28 Juni 2013.

Rangkuti, Freddy. 2002. Measuring Customer Satisfaction, Penerbit Gramedia Pustaka Utama, Jakarta.

Sagita, Fitria Engla. 2013. Pengaruh Brand Image dan Harga Terhadap Keputusan Pembelian Ulang Produk Kentucky Fried Chicken (KFC) di Cabang Basko Grand Mall oleh Mahasiswa Universitas Negeri Padang, ejournal.unp.ac.id/students/index.php/mnj/.../305. Diakses: 30 Juni 2013.

Schiffman, Leon G., \& Leslie Lazar Kanuk. 2007. Consumer Behavior, $9^{\text {th }}$ ed, PrenticeHall International, Inc., London.

Shimp, Terence A. 2003. Periklanan Promosi: Komunikasi Pemasaran Terpadu, Jilid 1, Penerbit Erlangga, Jakarta.

Sugiyono. 2008. Statistika untuk Penelitian, Penerbit Alfabeta, Bandung. 
Sutisna. 2001. Perilaku Konsumen dan Komunikasi Pemasaran, Penerbit Erlangga, Jakarta.

Sutisna dan Teddy Prawita. 2001. Perilaku Konsumen dan Strategi Pemasaran, Penerbit Remaja Rosdakarya, Bandung. 